\title{
A Morphological Analysis of the Suborbital Fossa (Fossa suborbitalis) in Genus Colobus
}

\author{
Shin Matsumoto \\ Primate Research Institute, Kyoto University
}

\begin{abstract}
The variability of the suborbital fossa of the three species of Colobus was analyzed morphologically through three approaches; craniometry, observation and dissection of the bone.

1. The variability of the fossae of the three species does not mean only presence in C.verus and C.badius or absence in C.polykomos.

2. The suborbital features of Colobus are recognized better synthetically by understanding variability of the fossae as that of two pillars which are observed at the orbital margin and at the corpus of the zygomatic bone.

3. In C.verus only the pillar at the orbital margin developes, in C.badius additionally the corpus of the zygomatic bone developes and projects forward with the frontal process of the bone and the robust zygomatic arch. In C.polykomos, despite of the common character of the genus, the enlarged zygomatic bone does not show the developments of any parts.
\end{abstract}

\section{INTRODUCTION}

It is well known that the suborvital fossa is very convenient in distinguishing the species of genus Colobus (Vogel 1962) and other primates (TAPPEN 1963).

The skull forms, of course, depends greatly on the degree of the development of the masticative muscles (VOGEL 1966). Concerning the fossa, however, it is inadequate to combine it with the development of the muscles directly. Because the fossa is originally the negative feature, in particular, we need to clarify the relations between it and the surrounding features. In addition, naming of the forms such as fossa or process is no more than discriminative. Although it is essential in description and comparison, we can find considerable variation even in individuals of one species. Therefore, instead of reg- arding the features of fossae as only discriminative ones and giving functional explanations, we need to define the concrete meaning of the variability of the fossa intraspecifically and interspecifically.

\section{MATERIALS AND METHODS}

The materials used are as follows: males females

$\begin{array}{lll}\text { Colobus verus : } & 26 & 33 \\ \text { 〔Colobus badius : } & 12 & 99 \\ \text { 〔Colobus polykomos : } & \frac{10}{48} & \frac{75}{207}\end{array}$

These specimens were collected in Nimba, Liberia, about 200 kilometers along the River Cess from the sea, which are kept in Primate Research Institute, Kyoto University. The specimens consist of various age groups, but in this study, only mature ones which show complete eruption of the 
third molars are used.

In the following, three different approaches will be shown to the features of the suborbital fossae in three species of genus Colobus. First the general features are craniometrically analyzed and several dimensions correlated to the fossa are also examined. Next the features around the fossa are observed and their variability is investigated. Finally the internal features, suture planes of the zygomatic and the maxillar bones are tested by dissection of the bones.

\section{CRANIOMETRY}

Nineteen measuring dimensions used are chiefly based on MARTIN-SALLER's "Lehrbuch der Anthropologie".

In Table 1 the results are shown. The measurements were carried to three significant figures. In almost all dimensions, males show greater values than females intraspecifically, with C.polykomos greater than $C$.badius and C.badius greater than C.verus interspecifically.

Table 2 shows the results of measurements on four dimensions and the significant differences between males and females as well as among species. In the mean breadth of (eurion-eurion), a significant sexual difference is seen only in C.polykomos, and the standard deviations are comparatively small as well. This dimension is thought to indicate the general character of the species. It is for this reason that this dimension is used as the denominators of indices later. Interspecifically all the three species of both sexes show significant differences to the $0.1 \%$ level. In the breadth of (zygion-zygion), (jugale-jugale) and (frontomalare temporale-frontomalare temporale) we can find significant differences to the $0.1 \%$ levels in each case intraspecifically and interspecifically.

Table 3 shows the indices, the ratios of the breadth of the latter three dimensions to that of (eu-eu), the meanings of which are physiognomically but not allometrically exact. In the indices of (zy$\mathrm{zy}) /(\mathrm{eu}-\mathrm{eu})$ and $(\mathrm{fmt}-\mathrm{fmt}) /(\mathrm{eu}-\mathrm{eu})$, a significant difference cannot be observed between C.badius and C.polykomos. C. verus, however, differs greatly from the other two species. In the index of ( $\mathrm{ju}$ $\mathrm{ju}) /(\mathrm{eu}-\mathrm{eu})$, there are significant differences among all the three species. All species indicate sexual differences in the three indices.

\section{EXTERNAL OBSERVATION}

The frontal views of the females of the three species are shown in Plate 1. Colobus monkeys generally exhibit little sexual dimorphism (NAPIER and NAPIER 1967). As for the crania, they have no marked differences except large canines in males. The morphological characters described below are common between both sexes as a species.

The prominence of the suborbital fossa is immediately obvious in C.verus and C.badius, while the suborbital part of $C$. polykomos is flat and plainly different from those of the other two species. Even from this character alone we can disting. uish C.polykomos from C.verus and $C$. badius.

Observed minutely, however, the suborbital flatplane of C.polykomos is found 


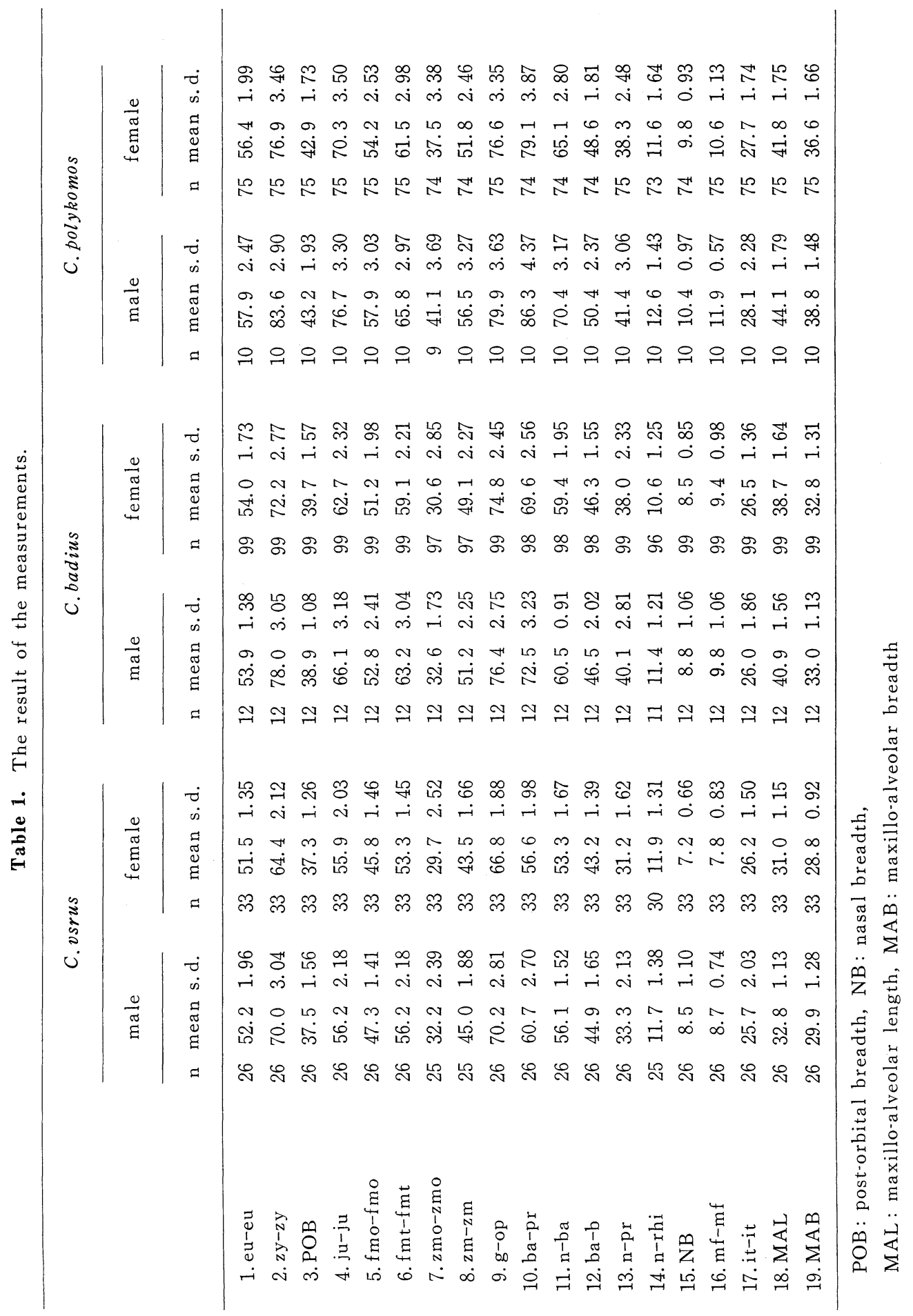


Table 2. Comparisons of the means and the variances for four items.

\begin{tabular}{|c|c|c|c|c|c|c|c|c|}
\hline \multicolumn{4}{|c|}{ male } & & \multicolumn{4}{|c|}{ female } \\
\hline $\mathrm{Cb}$ & $\mathrm{Cv}$ & $\begin{array}{c}\mathrm{sp} . \\
\mathrm{n}\end{array}$ & $\begin{array}{l}\text { mean } \\
\text { s.d. }\end{array}$ & & $\begin{array}{l}\text { mean } \\
\text { s.d. }\end{array}$ & $\begin{array}{c}\mathrm{sp} . \\
\mathrm{n}\end{array}$ & $\mathrm{Cv}$ & $\mathrm{Cb}$ \\
\hline *** & *** & $\begin{array}{l}\mathrm{Cp} \\
10\end{array}$ & $\begin{array}{l}57.9 \\
2.47 \\
\end{array}$ & * & $\begin{array}{l}56.4 \\
1.99 \\
\end{array}$ & $\begin{array}{l}\mathrm{Cp} \\
75 \\
\end{array}$ & $\begin{array}{l}* \star * * \\
-\end{array}$ & *** \\
\hline & * & $\begin{array}{l}\mathrm{Cb} \\
12\end{array}$ & $\begin{array}{l}53.9 \\
1.38\end{array}$ & - & $\begin{array}{l}54.0 \\
1.73\end{array}$ & $\begin{array}{l}\mathrm{Cb} \\
99\end{array}$ & - & \\
\hline & & $\begin{array}{l}\mathrm{Cv} \\
26\end{array}$ & $\begin{array}{l}52.2 \\
1.96\end{array}$ & - & $\begin{array}{l}51.5 \\
1.35\end{array}$ & $\begin{array}{l}\mathrm{Cv} \\
33\end{array}$ & & \\
\hline
\end{tabular}

$$
\text { zy }-z y
$$

\begin{tabular}{|c|c|c|c|c|c|c|c|c|}
\hline \multicolumn{4}{|c|}{ male } & & \multicolumn{4}{|c|}{ female } \\
\hline $\mathrm{Cb}$ & $\mathrm{Cv}$ & $\begin{array}{c}\mathrm{sp} . \\
\mathrm{n}\end{array}$ & $\begin{array}{l}\text { mean } \\
\text { s.d. }\end{array}$ & & $\begin{array}{l}\text { mean } \\
\text { s.d. }\end{array}$ & $\begin{array}{c}\mathrm{sp} . \\
\mathrm{n}\end{array}$ & $\mathrm{Cv}$ & $\mathrm{Cb}$ \\
\hline$\star \star \star$ & $\star \star \star *$ & $C p$ & 83.6 & $\star \star \star \star *$ & 76.9 & $c \mathrm{p}$ & $\star \star \star \star$ & $\star \star \star \star$ \\
\hline - & - & 10 & 2.90 & - & 3.46 & 75 & $\star \star$ & - \\
\hline & $\star \star \star \star *$ & $\mathrm{Cb}$ & 78.0 & $\star \star \star \star *$ & 72.7 & $\mathrm{Cb}$ & 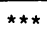 & \\
\hline & - & 12 & 3.05 & - & 2.77 & 99 & - & \\
\hline & & $\mathrm{Cv}$ & 70.0 & $\star \star \star *$ & 64.4 & $\mathrm{Cv}$ & & \\
\hline & & 26 & 3.04 & - & 2.12 & 33 & & \\
\hline
\end{tabular}

\begin{tabular}{|c|c|c|c|c|c|c|c|c|}
\hline \multicolumn{4}{|c|}{ male } & & \multicolumn{4}{|c|}{ female } \\
\hline $\mathrm{Cb}$ & $\mathrm{Cv}$ & $\begin{array}{c}\text { Sp. } \\
n\end{array}$ & $\begin{array}{l}\text { mean } \\
\text { s.d. }\end{array}$ & & $\begin{array}{l}\text { mean } \\
\text { s.d. }\end{array}$ & $\begin{array}{c}\mathrm{sp} . \\
\mathrm{n}\end{array}$ & $\mathrm{Cv}$ & $\mathrm{Cb}$ \\
\hline 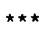 & $\star \star \star \star$ & $\mathrm{Cp}$ & 76.7 & $\star \star *$ & 70.3 & $\mathrm{CP}$ & $\star \star \star \star$ & 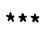 \\
\hline \multirow[t]{5}{*}{-} & - & 10 & 3.30 & - & 3.50 & 75 & $* *$ & $* \star \star *$ \\
\hline & $\star \star \star \star$ & $\mathrm{Cb}$ & 66.1 & 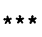 & 62.7 & $\mathrm{Cb}$ & $\star \star \star \star$ & \\
\hline & - & 12 & 3.18 & - & 2.32 & 99 & - & \\
\hline & & $\mathrm{CV}$ & 59.3 & $\star \star \star \star$ & 55.9 & $\mathrm{Cv}$ & & \\
\hline & & 26 & 2.24 & - & 2.03 & 33 & & \\
\hline
\end{tabular}

\begin{tabular}{|c|c|c|c|c|c|c|c|c|}
\hline \multicolumn{4}{|c|}{ male } & & \multicolumn{4}{|c|}{ female } \\
\hline $\mathrm{Cb}$ & $\mathrm{Cv}$ & $\begin{array}{c}\mathrm{sp} . \\
\mathrm{n}\end{array}$ & $\begin{array}{l}\text { mean } \\
\text { s.d. }\end{array}$ & & $\begin{array}{l}\text { mean } \\
\text { s.d. }\end{array}$ & $\begin{array}{c}\mathrm{sp} \\
\mathrm{n}\end{array}$ & $\mathrm{Cv}$ & $\mathrm{cb}$ \\
\hline - & *** & $\begin{array}{l}\mathrm{Cp} \\
10\end{array}$ & $\begin{array}{l}65.8 \\
2.97\end{array}$ & *** & $\begin{array}{l}61.5 \\
2.98\end{array}$ & $\begin{array}{l}\mathrm{Cp} \\
75\end{array}$ & $\begin{array}{l}\star \star \star * \\
\star \star \star *\end{array}$ & $\stackrel{\star \star \star}{*}$ \\
\hline & $\begin{array}{l}* \star * \\
-\end{array}$ & $\begin{array}{l}\mathrm{Cb} \\
12\end{array}$ & $\begin{array}{l}63.2 \\
3.04\end{array}$ & $\begin{array}{l}* \star \star \\
-\end{array}$ & $\begin{array}{l}59.1 \\
2.21\end{array}$ & $\begin{array}{l}\mathrm{Cb} \\
99\end{array}$ & $\begin{array}{c}* * * \\
*\end{array}$ & \\
\hline & & $\begin{array}{l}\mathrm{CV} \\
26 \\
\end{array}$ & $\begin{array}{l}56.2 \\
2.18\end{array}$ & $\begin{array}{c}* \star \star \\
\star\end{array}$ & $\begin{array}{l}53.3 \\
1.45 \\
\end{array}$ & $\begin{array}{l}\mathrm{Cv} \\
33\end{array}$ & & \\
\hline
\end{tabular}

F-test was used for the comparisons of the variances and $t$-test and the modified t-test (ASPIN-WELCH method) for the means.

-: without significant difference, *: significant difference at the $5 \%$ level, **: significant difference at the $1 \%$ level, $* * *$ : significant difference at the $0.1 \%$ level.

Table 3. Comparisons of the three indices. The values are centuplicated.

$(z y-z y) /(e u-e u)$

\begin{tabular}{|c|c|c|c|c|c|c|c|c|}
\hline \multicolumn{4}{|c|}{ male } & & \multicolumn{4}{|c|}{ female } \\
\hline $\mathrm{Cb}$ & $\mathrm{Cv}$ & $\begin{array}{c}\mathrm{sp} . \\
\mathrm{n}\end{array}$ & $\begin{array}{l}\text { mean } \\
\text { s.d. }\end{array}$ & & $\begin{array}{l}\text { mean } \\
\text { s.d. }\end{array}$ & $\begin{array}{c}\mathrm{sp} \\
\mathrm{n}\end{array}$ & $\mathrm{Cv}$ & $\mathrm{Cb}$ \\
\hline- & $\begin{array}{c}\star \star \star \\
\star\end{array}$ & $\begin{array}{l}C p \\
10 \\
\end{array}$ & $\begin{array}{l}147 . \\
7.76 \\
\end{array}$ & $\begin{array}{l}\star \star \\
\star\end{array}$ & $\begin{array}{l}136 . \\
4.81\end{array}$ & $\begin{array}{l}C p \\
75\end{array}$ & *** & - \\
\hline & $\begin{array}{l}\star \star \star * \\
-\end{array}$ & $\begin{array}{l}\mathrm{Cb} \\
12 \\
\end{array}$ & $\begin{array}{l}148 . \\
5.70 \\
\end{array}$ & ${ }^{* * *}$ & $\begin{array}{l}135 . \\
5.46 \\
\end{array}$ & $\begin{array}{l}\mathrm{Cb} \\
99 \\
\end{array}$ & *** & \\
\hline & & $\begin{array}{l}\mathrm{Cv} \\
26\end{array}$ & $\begin{array}{l}134 . \\
4.42\end{array}$ & *** & $\begin{array}{l}125 . \\
4.28\end{array}$ & $\begin{array}{l}\mathrm{CV} \\
33\end{array}$ & & \\
\hline
\end{tabular}

\begin{tabular}{|c|c|c|c|c|c|c|c|c|}
\hline \multicolumn{4}{|c|}{ male } & & \multicolumn{4}{|c|}{ female } \\
\hline $\mathrm{Cb}$ & $\mathrm{Cv}$ & $\begin{array}{c}\mathrm{Sp} \\
\mathrm{n}\end{array}$ & $\begin{array}{l}\text { mean } \\
\text { s.d. }\end{array}$ & & $\begin{array}{l}\text { mean } \\
\text { s.d. }\end{array}$ & $\begin{array}{c}\mathrm{sp} \\
\mathrm{n}\end{array}$ & $\mathrm{Cv}$ & $\mathrm{Cb}$ \\
\hline- & ** & $\begin{array}{l}\mathrm{Cp} \\
10\end{array}$ & $\begin{array}{l}114 . \\
5.68\end{array}$ & ** & $\begin{array}{l}109 . \\
4.56\end{array}$ & $\begin{array}{l}\mathrm{Cp} \\
75\end{array}$ & *** & - \\
\hline & *** & $\begin{array}{l}\mathrm{Cb} \\
12\end{array}$ & $\begin{array}{l}117 . \\
5.79\end{array}$ & *** & $\begin{array}{l}110 . \\
4.53\end{array}$ & $\begin{array}{l}\mathrm{Cb} \\
99\end{array}$ & - & \\
\hline & & $\begin{array}{l}\mathrm{CV} \\
26\end{array}$ & $\begin{array}{l}108 . \\
4.15\end{array}$ & *** & $\begin{array}{l}104 . \\
3.69\end{array}$ & $\begin{array}{l}\mathrm{Cv} \\
33\end{array}$ & & \\
\hline
\end{tabular}

\begin{tabular}{|c|c|c|c|c|c|c|c|c|}
\hline \multicolumn{4}{|c|}{ male } & & \multicolumn{4}{|c|}{ female } \\
\hline $\mathrm{Cb}$ & $\mathrm{Cv}$ & $\begin{array}{c}\text { Sp. } \\
n\end{array}$ & $\begin{array}{l}\text { mean } \\
\text { s.d. }\end{array}$ & & $\begin{array}{l}\text { mean } \\
\text { s.d. }\end{array}$ & $\begin{array}{c}\mathrm{sp} . \\
\mathrm{n}\end{array}$ & $\mathrm{CV}$ & $\mathrm{Cb}$ \\
\hline$\star \star$ & $\star \star \star *$ & $C p$ & 133. & $\star \star \star *$ & 125. & $\mathrm{Cp}$ & $\star \star \star *$ & $\star \star \star \star$ \\
\hline- & - & 10 & 6.54 & - & 5.29 & 75 & - & - \\
\hline & $\star \star \star$ & $\mathrm{Cb}$ & 123. & $\star * *$ & 116. & $\mathrm{Cb}$ & $\star \star \star *$ & \\
\hline & - & 12 & 6.27 & - & 4.92 & 99 & - & \\
\hline & & $\mathrm{Cv}$ & 114. & $\star \star \star *$ & 109. & $\mathrm{Cv}$ & & \\
\hline & & 26 & 4.17 & - & 4.33 & 33 & & \\
\hline
\end{tabular}


not to preclude the existence of the fossa. The suborbital suture line of C.polykom$o s$, as well as in C.verus and C.badius, runs from the lower edge of the orbit laterally and, through the turning point, goes down to the zygomatic-alveolar crest. And below the suture, the hollow is clearly visible medially and a little superiorly from the zygomatic-alveolar crest. The fossae of C.verus and C.badius are both outstanding but differ from each other in detail.

In C.verus, the suborbital fossa is contiguous laterally smoothly to the under edge of the zygomatic arch. This is the case even when the insertion area of the masseter muscle is outstanding or when the zygomatic-alveolar crest developes strongly. And the suborbital part including the fossa as a whole faces the front a little laterally. The fossa is deep from the suborbital crest. The lateral side of the frontal process convexly curves and the zygomatic arch stands relatively higher than that of C.badius or C.polykomos. In C.verus the margin of the orbit developes comparatively well but neither the lateral side of the frontal process nor the zygomatic arch project forward at all.

In C.badius, when compared with $C$. verus, the suborbital fossa ends laterally as a round arc. The suborbital part as a whole faces the front almost squarely. That is, adding to the development of the margin of the orbit, the whole frontal process and especially the anterior part, the corpus of the zygomatic bone project forward strongly.

\section{INTERNAL OBSERVATION}

The development of the zygomatic bone in specific directions must be reflected on the internal surface of the bone. Comparing the features of the internal surfaces of the bones in the three species, we can distinguish the more exact characteristics of the external variability.

For these reasons, using a dental apparatus, Torx, the maxillar bone was gradually removed in order to observe the suture plane of the zygomatic bone. Then, after the frontal process, the temporal process and the orbital surface were cut through, the zygomatic bone was removed. These are shown in Plate 1. Materials are six in all, one for each sex of each species. The characters thought to be general as the species are described below.

The suture plane of the zygomatic bone to the maxillar bone is divided into four parts; Facies frontalis, lateralis, inferior and medialis. Facies frontalis is contiguous to the frontal suture line of the $z y$ gomatic and the maxillar bones. The latter bone overlies this part of the former. The suture line indicates only the external trace of the connection of these two bones. Facies lateralis constitutes the inner surface of the temporal border of the temporal border of the zygomatic bone and is perpendicular sagittally to frontalis. Facies inferior is the lower part and inclines caudally to frontalis and medially to lateralis. Facies medialis, adjacent medially to frontalis and inferior, constitutes the orbital margin. On the medial and the lateral side of the plane, we can observe many folds. 

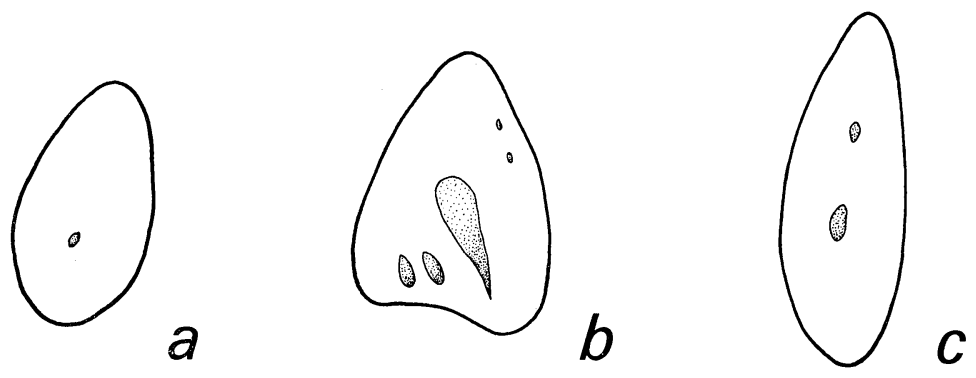

Fig. 1. The schematic forms of the vertical sections of the zygomatic arches (temporal process of the zygomatic bone).

$a$ : Colobus verus, $b$ : Colobus badius, $c$ : Colobus polykomos

The scale indicates $0.5 \mathrm{~mm}$.

Left lateral, right medial.

In C.badius, these four parts are distinguished easily. Each boundary of these parts is rather clear. The most important character is the breadth of Facies inferior. In C.verus, lateralis and inferior are small and the boundary of frontalis and inferior is vague. The plane as a whole faces the fronto-inferior direction. That is, the pillar surrounding the orbit is ascertained clearly, but other parts do not show the developments. In C. polykomos, frontalis faces the frontal direction independently. But inferior is never broad, almost appears to be the inner surface of the orbit.

Through these dissections, the vertical sections of the zygomatic arches were also gained and they are shown in Fig. 1. It is outstanding that in C.badius the section is thick and in C.polykomos very thin.

\section{DISCUSSION}

It is obvious that the variability of the suborbital fossa does not mean only presence in C.verus and C.badius and abse- nce in C.polykomas. More precisely, we cannot deny the existence of the fossa in C. polykomas, and there is a clear difference between the lateral ends of the fossae of C.verus and C. badius.

Accordingly, for an understanding of this variability, the best way is to identify the general characters as genus Colobus and then to point out the specializations of the three species. Although the growth of the fossa is resorptive in a positive sence, its existence is characterized by the developments of the margins of the fossa.

As the fundamental feature of the suborbital part in the genus, we can recognize two pillars. One is that surrounding the orbit, and the other is the pillar from the lateralo-inferior part of the former to the insertion area of the masseter muscle. The former is thought to relate to biting and chewing actions directly, and the latter seems to be concerned with development of the masseter muscle.

The specialization of the suborbital part of C.verus is thickness and the forward 
projection of the orbital margin. But this is not followed by the development of the zygomatic bone itself, as seen in the lateral side of the frontal process and the lower part of the suborbital area. As for the suture plane, the pillar constituting the orbital margin is conspicuous, but the plane as a whole inclines infero-caudally. And the fact that the boundaries of the four parts are not clear, as well as the little development of inferior, supports the conclusion that the characteristics of this area in C.verus is only the development of the pillar at the orbital margin. This explains the craniometrical results that these three indices are smaller in C. verus than those of the other two species.

In $C$. badius, adding to the marginal development, the lateral side of the frontal process and the whole zygomatic arch is advanced robustly. Especially the forward advancement of the anterior part of the temporal process makes the lateral end of the fossa a round arc. As for the suture plane, inferior broadens very $\mathrm{mu}^{-}$ ch. In relation to this, frontalis faces the front squarely and, with lateralis, is angled to inferior. The whole zygomatic bone is found to develope forward strongly.

In C.polykomos, the advancement of special parts cannot be recognized. The whole suture plane is small, ocntrary to the largeness of the zygomatic bone. This bone in C.polykomos, is a flattened large one, which may not be the result of the special mechanical forces. Its suture plane has no more meaning than adjoing to the maxillar bone. The whole large- ness of the bone seems to explain the difference of the index of $(j u-j u) /(e u$ - eu) from C.badius, in which the anterior part of the zygomatic arch projects forward.

Thus, each of three species shows a special attribute related to the feature of the suborbital fossa instead of its mere presence or absence.

\section{ACKNOWLEDGEMENT}

The author wishes to express the deepest appreciation to Professor Dr. A. Ehara, Primate Research Institute, Kyoto University, for his valuable suggestions throughout this study. The author also wishes to thank greatly Professor Dr. Y. Nogami, Mr. M. Kinoshita, the same institute, and R. MARShall, University of Pittsburgh, for their kind advice in the preparation of the manuscript.

\section{REFERENCES}

Ehara, A., and R. Seiler, 1970: Die Strukturen der Überaugenregion bei den Primaten. Deutungen und Definition. Z. Morph. Anthrop., 62 (1): 1-29.

EHARA, A., 1972: Morphologische Analyse über Variabilität und funktionelle Bedeutung der Jochbogenform bei Latarrhinen Primaten. Z. Morph. Anthrop., 63 (3): 351-369.

Endo, B., and Y. FukushimA, 1973: Untersuchungen zur Beanspruchung des menschlichen Gesichtsschädels beim Kauen mittels der zweidimensionalen spannungsoptischen Methode. Okajima's Fol. Anat. Jap., 49 : 413432.

ENLOW, D. H., 1966: A comparative study of facial growth in Homo and Macaca. Am J. Phys. Anthrop., 24: 293-308.

MARTIN, R., and K.SALLER, 1957: Lehrbuchder Anthropologie, 3 Auf1, Bd. I. Gustav Fischer, Stuttgart, 429-488.

NAPier, J. R., and P. H. NAPier, 1967: A handbook of living primates. Academic Press, 
London-New York, 123-131.

TAPPEN, N.C., 1963: Genetics and systematics in the study of primate evolution. Symp. Zool. Soc. Lond. , 10: 267-276.

VERHEYEN, W. N., 1962: Contribution à la craniologie comparée des Primates. Musée Roy. Afrique Centrale-Tervuren, Belgique. Ser. 8. Sci. Zool., 105: 1-256.

VoGel, C., 1962: Untersuchungen an Colobus-
Schädeln aus Liberia unter besonderer Berücksichtigung der Crista Sagittalis. Z. Morph. Anthrop., : 52 (3):306-332.

Vogel, C., 1966: Morphologische Studien am Gesichtsschädel catarrhiner Primaten. Bibliotheca Morphologica Fasc 4, Basel-New York, 1-226.

(Received April 1. 1978)

コロブス属における Fossa suborbitalis の形態学的分析

\author{
松本真 \\ 京都大学霊長類研究所
}

Colobus 属 3 種の Fassa suborbitalis の変異性を, 頭蓋計測, 外部観察および骨解剖による内部観察の三 つの方法によって形態学的に分析し, 次の結論を得た。

1. 3 種の上記 fossa の変異性は, C. verus およびC.badius において顕著で, C. polykomos には見られな いといった存在の有無以上の意義を有している。

2.Colobus 属の上記 fossa を含む眼窩下部の形態は, 眼窩縁部および牛具体部における二つの Pfeiler (pillar）を基本的な構造として捉え，その変異性を議論することにより，よく理解される。

3. C. verus においては眼窩縁部の Pfeiler のみが著しく発達し，C.badius では更に頉骨体部が前頭突起， 側頭突起とと屯に前方に突出しょく発達している。C.polykomos に招いては基本構造は見られるが，特定の 部分の発達はない。

以上によって，上記 fossa を中心とした様々な形態特徵を統一的に説明できる。 

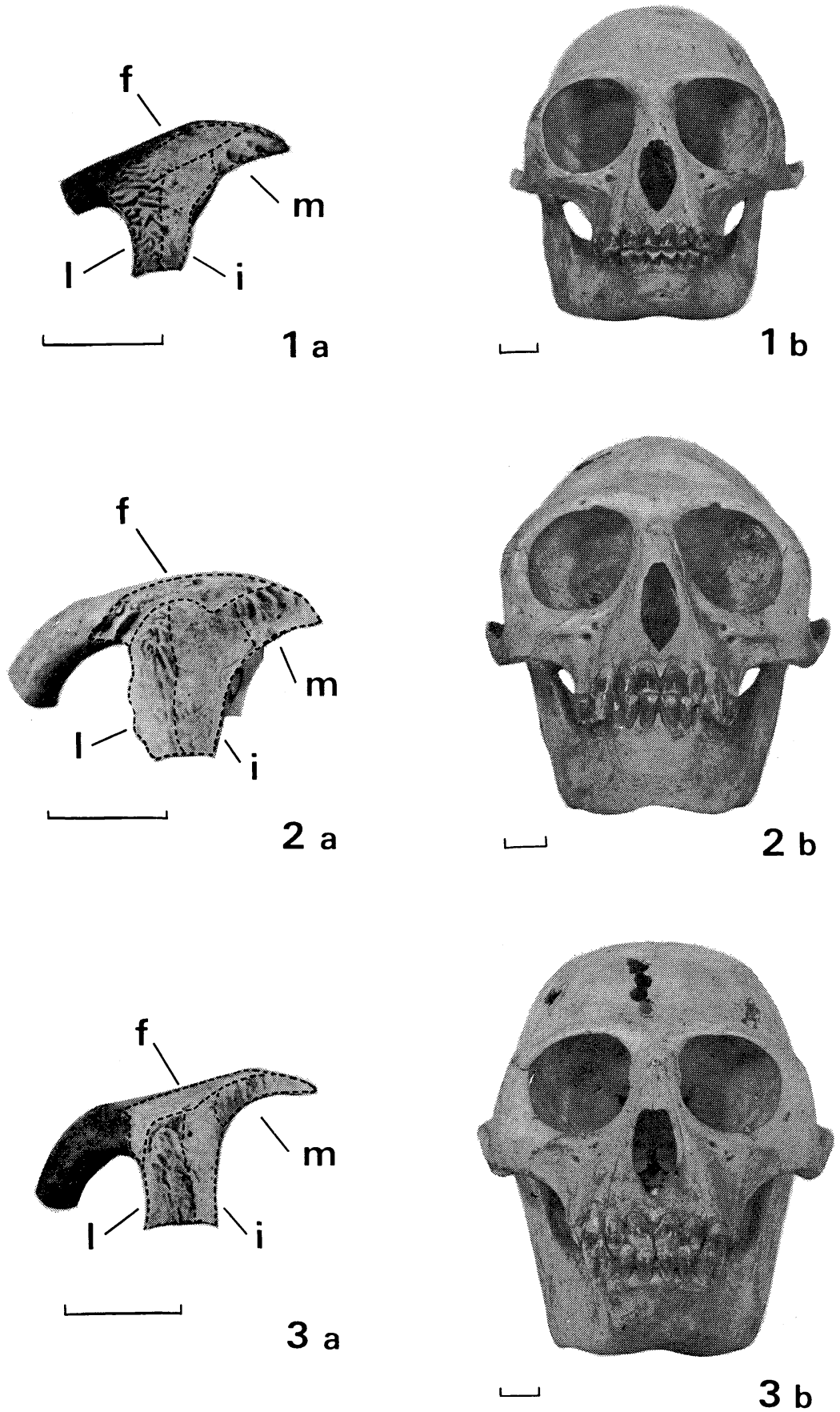

Plate 1. The frontal views of the females of the three species of genus Colobus ( $1 \mathrm{~b}, 2 \mathrm{~b}, 3 \mathrm{~b}$ ) and the underside views of the removed right zygomatic bones of females (1a,2a,3a). $1 \mathrm{a}, 1 \mathrm{~b}:$ Colobus verus $2 \mathrm{a}, 2 \mathrm{~b}$ : Colobus badius 3a,3b: Colobus polykomos

$\mathrm{f}$ : Facies frontalis 1: Facies lateralis i: Facies inferior $\mathrm{m}$ : Facies medialis Each scale indicates one centimeter. 